Rev. Int. Contam. Ambie. 37, 7-19, 2021

https://doi.org/10.20937/RICA.53508

\title{
IDENTIFICATION OF MINING RESIDUAL POLLUTANTS IN THE SONORA RIVER BASIN (NORTHWESTERN MEXICO) USING THERMOMAGNETIC MEASUREMENTS
}

\author{
Identificación de contaminación residual por minería en la cuenca del río Sonora \\ (noroeste de México) mediante mediciones termomagnéticas
}

\author{
Hermenegildo BARCEINAS CRUZ ${ }^{1 *}$, Beatriz ORTEGA GUERRERO², \\ Francisco MARTÍN ROMERO ${ }^{3}$, Sergey $\mathrm{SEDOV}^{4}$ and Daniel RAMOS PÉREZ ${ }^{5}$
}

${ }^{1}$ Posgrado en Ciencias de la Tierra, Instituto de Geofísica, Universidad Nacional Autónoma de México, Av. Universidad 3000, Ciudad Universitaria, 04520 Ciudad de México, México.

${ }^{2}$ Instituto de Geofísica, Universidad Nacional Autónoma de México, Av. Universidad 3000, Ciudad Universitaria, 04520 Ciudad de México, México.

${ }^{3}$ Instituto de Geología y Laboratorio Nacional Geoquímica y Mineralogía, Universidad Nacional Autónoma de México, Av. Universidad 3000, Ciudad Universitaria, 04520 Ciudad de México, México.

${ }^{4}$ Instituto de Geología, Universidad Nacional Autónoma de México, Av. Universidad 3000, Ciudad Universitaria, 04520 Ciudad de México, México.

${ }^{5}$ Posgrado en Ciencias de la Tierra, Instituto de Geología, Universidad Nacional Autónoma de México, Av. Universidad 3000, Ciudad Universitaria, 04520 Ciudad de México, México.

*Author for correspondence: gildo@comunidad.unam.mx

(Received: January 2019; accepted: January 2020)

Key words: thermomagnetic curves, mine wastes, jarosite.

\begin{abstract}
In Cananea, Sonora (northwestern Mexico), occurred a spilling of $40000 \mathrm{~m}^{3}$ of an acid solution coming from the Buenavista del Cobre mine, which reached some tributaries and the main water stream of the Sonora River basin. This study aims to evaluate magnetic properties as proxies to assess residual pollution in soils and sediments affected by this kind of events. Particularly, the study focused on the temperature dependence of magnetic susceptibility. Measurements of volume magnetic susceptibility vs temperatures were performed, heating samples to $700{ }^{\circ} \mathrm{C}$ and cooling them back to room temperature. A strong increase (from three to six times the initial value) of magnetic susceptibility during heating was observed on precipitates of the acid solution dam, and on affected soils and sediments, starting at $\sim 330^{\circ} \mathrm{C}$, and reaching a maximum at $\sim 430^{\circ} \mathrm{C}$. An even stronger increase was observed during cooling. These increases are due to the transformation of iron bearing minerals (as jarosite, goethite and ferrihydrite) to ferrimagnetic iron oxides (as magnetite). Samples of non-affected soils and sediments did not exhibit this increase during heating, but a decrease at $\sim 550^{\circ} \mathrm{C}$ related to (titano) magnetite Curie temperature, and they presented lower $\kappa$ values during cooling. The transformation of these iron-bearing minerals (commonly occurring in mine wastes and acid drainage) marked by a strong $\kappa$ increase during heating, can be used as an indicator of the presence of residual pollution.
\end{abstract}

Palabras clave: curvas termomagnéticas, residuos mineros, jarosita. 


\section{RESUMEN}

En Cananea, Sonora (noroeste de México), ocurrió un derrame de $40000 \mathrm{~m}^{3}$ de solución ácida proveniente de la mina Buenavista del Cobre, el cual alcanzó algunos tributarios y el cuerpo principal de agua de la cuenca del Río Sonora. El objetivo de este estudio fue evaluar el uso de propiedades magnéticas como indicadores de contaminación residual en suelos y sedimentos afectados por este tipo de eventos. El estudio se enfocó particularmente a la dependencia de temperatura de susceptibilidad magnética. Se llevaron a cabo mediciones de susceptibilidad magnética volumétrica vs temperatura, calentando las muestras hasta $700^{\circ} \mathrm{C}$ y enfriándolas despuésa temperatura ambiente. Se observó un fuerte aumento de la susceptibilidad magnética durante el calentamiento en muestras de precipitados del represo de la solución ácida, y en muestras de suelos y sedimentos afectados, comenzando a $\sim 330^{\circ} \mathrm{C}$ y alcanzando su máximo a $\sim 430^{\circ} \mathrm{C}$. Se observó un incremento aún mayor durante el enfriamiento, el cual se debió a la transformación de minerales portadores de hierro (como jarosita, goethita y ferrihidrita) en óxidos de hierro ferrimagnéticos (como magnetita). Las muestras de suelos y sedimentos no afectados no exhibieron este incremento durante el calentamiento, sino una disminución a $\sim 550^{\circ} \mathrm{C}$, relacionada con la temperatura de Curie de la (titano)magnetita. Dichas muestras presentaron valores de $\kappa$ más bajos durante el enfriamiento. La transformación de estos minerales portadores de hierro (muy comúnmente encontrados en desechos de mina y drenajes ácidos), marcada por el fuerte incremento de $\kappa$ durante el calentamiento, puede utilizarse como indicador de la presencia de contaminación residual.

\section{INTRODUCTION}

The use of magnetic properties of rocks as indirect indicators of the presence of residual pollution due to metallurgic activities is a widely used method to assess contaminated areas. Several studies report a strong correlation between anthropogenic magnetic particles and heavy metals in different depositional environments as urban dust (Zhu et al. 2013), soils (Strzyszcz and Magiera 1998), and lake and river sediments (Scholger 1998, Yang et al. 2007, Chaparro et al. 2011). These studies have also been applied in areas affected by mining and smelting activities (Magiera et al. 2016, 2018) and metallurgic and mining wastes (Peña et al. 2013).

However, most of the cited literature reports an enhancement of magnetic susceptibility because the process that generates magnetic particles implies roasting over $350{ }^{\circ} \mathrm{C}$ of iron-bearing minerals that alter to iron oxides. But when the extraction process is carried out at room temperature, as in hydrometallurgic processes of metals extraction, the magnetic susceptibility enhancement is not clearly reflected (Matasova et al. 2005, Pérez 2015). Mineralogy of iron-bearing secondary products from hydro-metallurgic processes is well characterized (Jambor and Owens 1993; Blowes et al. 2003), but their magnetic properties are not deeply studied because of their paramagnetic behavior, and they do not significantly contribute to a magnetic susceptibility enhancement.

In September 2014, a leak from a dam containing a solution of sulfuric acid occurred in a mine near Cananea, Sonora, northwestern Mexico, affecting the hydrological basin of the Sonora River (Fig. 1). Lixiviation and electro-gain in acid solution is a common hydrometallurgy method used by mining companies to extract copper from a copper porphyry. After the spilling incident, the company tried to remediate and mitigate the impact by neutralizing the solution using lime and by recollecting manually (with shovels) the spilled material from the fluvial sediments in the riverbank.

Afterwards, some geochemical studies have been performed trying to assess the presence of residual pollutants that may represent a risk for flora, fauna and human health in the area. Nevertheless, those studies did not get conclusive results, due to the geochemistry of the area that naturally presents high contents of heavy metals (Calmus et al. 2018). Some studies have used geophysical indirect indicators as electrical conductivity and magnetic susceptibility (Ramos 2017), but it was also observed that the natural presence of some minerals with high values of these properties makes difficult to distinguish the contribution of pollutants. 


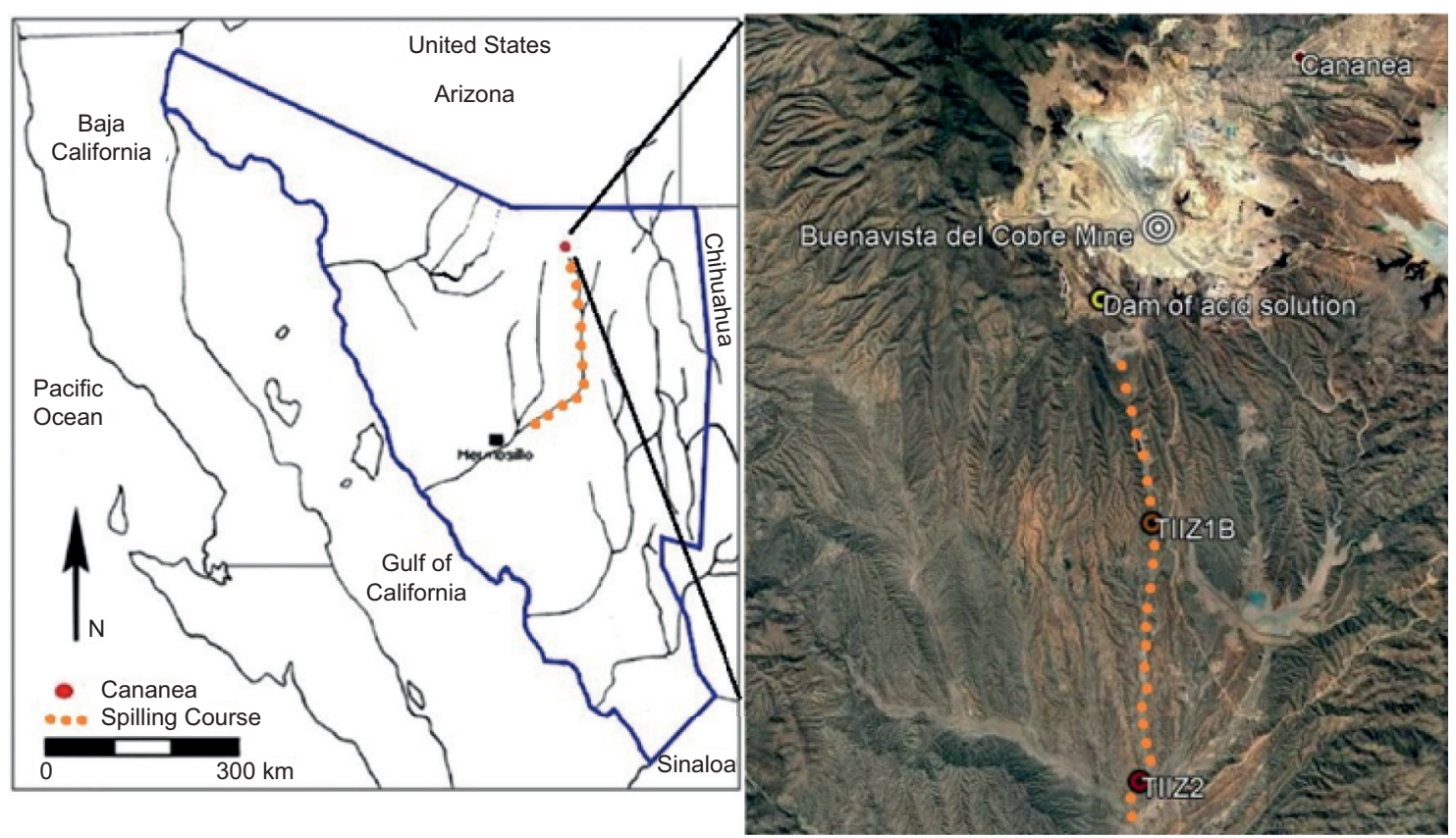

Fig. 1. Location of Cananea, Sonora (left), and Google Earth image with the location of sampling sites and spilling course (right).

In previous studies it has been concluded that the most suitable trackers of residual pollution are iron oxyhydroxysulfates such as jarosite, and iron oxyhydroxides such as ferrihydrite, which precipitated in the acid solution from the dam and dragged down to the fluvial sediments during the leak. It is easy to detect the presence of these materials in field due to their ochre-yellowish pigmentation (Rivera et al. 2018). However, these minerals are not easy to characterize analytically due to their amorphous structure and very small particle sizes.

The temperature dependence of magnetic susceptibility is widely used to identify magnetic mineralogy, but it is more commonly used for the identification of iron oxides. It is also well known that some iron-bearing minerals undergo mineralogical transformation into strongly magnetic iron oxides during heating. For instance, Mitov et al. (2002) studied the transformation of synthetic samples of iron oxyhydroxides (goethite, lepidocrocite and ferrihydrite) to iron oxides (magnetite and hematite). Other works (e.g., Hanesch et al. 2006, Abrajevitch and Kodama 2011, Quijano et al. 2014) studied the thermomagnetic behavior of soil and sediment samples and reported an increase in magnetization during heating due to the transformation of iron oxides and hydroxides to ferrimagnetic iron oxides. The magnetic properties of iron sulfates have been less studied since they are weakly magnetic, but thermochemical studies have reported that they transform to iron oxides due to heating (Frost et al. 2005, 2007). Some authors have studied the temperature dependence of magnetic properties and proposed parameters to quantify the degree of mineral alteration of iron minerals (e.g., Böhnel et al. 2002, Hrouda 2003, Abrajevitch and Kodama 2011).

This work aims to detect the presence of residual material from the acid solution spilling in fluvial sediments of the Tinajas river (a tributary seasonal stream of the Sonora river), using the thermomagnetic properties of the material. In this case, pollutants are not strongly magnetic and their magnetic signal is masked by the magnetic properties of natural material. However, the presence of pollutants can be detected by the transformation of iron oxyhydroxisulfates (as jarosite) into iron oxides (as magnetite and hematite), as this transformation occurs at a specific temperature during heating.

\section{MATERIALS AND METHODS}

\section{Study area}

The study area is located in northwestern Mexico (Sonora state), in the Cananea mining district (Fig. 1).

This area is part of the Sierra Madre Occidental 
mountain range, formed by batholitic and volcanic rocks from the Mesozoic to Paleogene ages (80 to $40 \mathrm{Ma})$, emplaced over Precambrian granitic and metamorphic rocks (Ochoa-Landín et al. 2011). The type of mineral deposits is copper porphyry and it include large areas of hydrothermal alterations, mostly related to sub-volcanic and hypabyssal bodies, varying in composition from monzonite to quartz-diorite (Ochoa-Landín and Echávarri 1978).

The Buenavista del Cobre mine has a $7140 \mathrm{Mt}$ deposit with $0.42 \%$ of $\mathrm{Cu}$. The mineralization is found mainly in volcanic rocks of the Henrietta and Mesa formations, intruded by porphyry bodies. The $\mathrm{Cu}$ mineralization is almost horizontal, extended over an area of $15 \mathrm{~km}^{2}$ and reaching a maximum thickness of $500 \mathrm{~m}$ (del Río-Salas et al. 2015).

Hydrologically, the study area is in the basin of the Sonora river, in which Quaternary alluvial deposits and Tertiary conglomerates, limestones and silts are considered as the main producers and the transmitters of water. The mountains limiting the valley are formed by Tertiary volcanic rocks with good permeability due to the presence of fractures and cretaceous igneous rocks (Vega-Granillo et al. 2011). The Sonora River basin comprises a net of tributary rivers and creeks, of which the Tinajas River (a seasonal tributary in the northwestern part of the basin) is our specific study area, due to its proximity to the Buenavista del Cobre mine, so it constitutes the area most directly affected by the spill.

According to Calmus et al. (2018), rocks from the area have a high content of heavy metals and, in consequence, river sediments in the area have inherited a high amount of heavy metal content from the rocks.

\section{Sampling}

To carry out this study three sampling points along the Tinajas River were selected. A sample of the dam precipitate was taken to characterize the material coming from the mine. To characterize natural materials, samples of soil and sediments out of the course of the leak were taken, these samples were selected for their topographical position, high enough to be sure the leak did not affect them. To assess the residual pollution in the affected area, samples on the river margin were taken. This last sampling point was selected for its marked yellowish coloration, very characteristic of the spilled material, contrasting with the reddish-brown coloration of soil and sediments of the zone.

The sampling from dam precipitates consisted of one composed sample of sediments from the bottom of the Tinajas I acid solution dam, within the Buenavista del Cobre mine facilities, where the spilled material came from, located in the uppermost part of the Tinajas River (UTM coordinates X: 0562460, Y: 3421922). It presents a clay-silty texture and an orange-yellowish coloration (Ramos 2017).

The samples of the non-affected materials were taken from a profile named TIIZ2 (UTM coordinates: X: 0563755, Y: 3408446), which consists of an approximately $10 \mathrm{~m}$ thick sequence paleosols, alluvial sediments and a poorly developed modern topsoil. The modern topsoil and the alluvial sediments directly beneath it are around $10 \mathrm{~m}$ above the stream level, so one sample from each of these two layers were taken and are considered as non-affected material (Romero 2018).

The samples of the material to evaluate were taken from the profile named TIIZ1B (UTM coordinates: X: 0563986, Y: 3415429), which consists of a $130 \mathrm{~cm}$ thick profile, formed by five horizons (AC, C, 2AC, C and 3C) with poorly developed pedogenic features (Fig. 2). A sharp color change was visible in this profile. While the upper part exhibited a dark brownish color (10YR2/210 YR2.5/2, according to the Munsell scale), the lower part, from 70 to $124 \mathrm{~cm}$, presented a yellowish pigmentation (10Yr3/3-10YR3/6, Munsell scale) (Romero-Lázaro et al. 2019). This suggests that the lower part was affected by the acid solution leak (based on the presence of yellowish precipitates), while the upper part was not affected (based on the lack of yellow precipitates). In order to detect the extension in which the lower part was affected, a horizontal profile was dug from the surface to 34 $\mathrm{cm}$ of depth inside the $2 \mathrm{C}$ horizon, at $90 \mathrm{~cm}$ from the top. During this procedure, it was observed that the yellow pigmentation was superficial in the horizon and disappeared at $24 \mathrm{~cm}$ of depth (Fig. 2). A total of five samples were taken from the TIIZ1B vertical profile, one for each horizon, and five more from the TIZ1B horizontal profile, one each $6 \mathrm{~cm}$.

\section{Low-frequency mass normalized magnetic sus- ceptibility $\left(\chi_{\text {Iff }}\right)$ and frequency-dependent magnetic susceptibility $\left(\chi_{\mathrm{fd} \%}\right)$}

For magnetic susceptibility measurements, samples were air-dried, gently crushed, tightly packed into acrylic boxes of $8 \mathrm{~cm}^{3}$ volume and weighted. A MS2 Bartington Magnetic Susceptibility Meter was used to measure volume magnetic susceptibility $(\kappa)$, with a dual sensor MS2B in low $(0.47 \mathrm{kHz})$ and high $(4.7 \mathrm{kHz})$ frequency. Low-frequency magnetic susceptibility was calculated by 

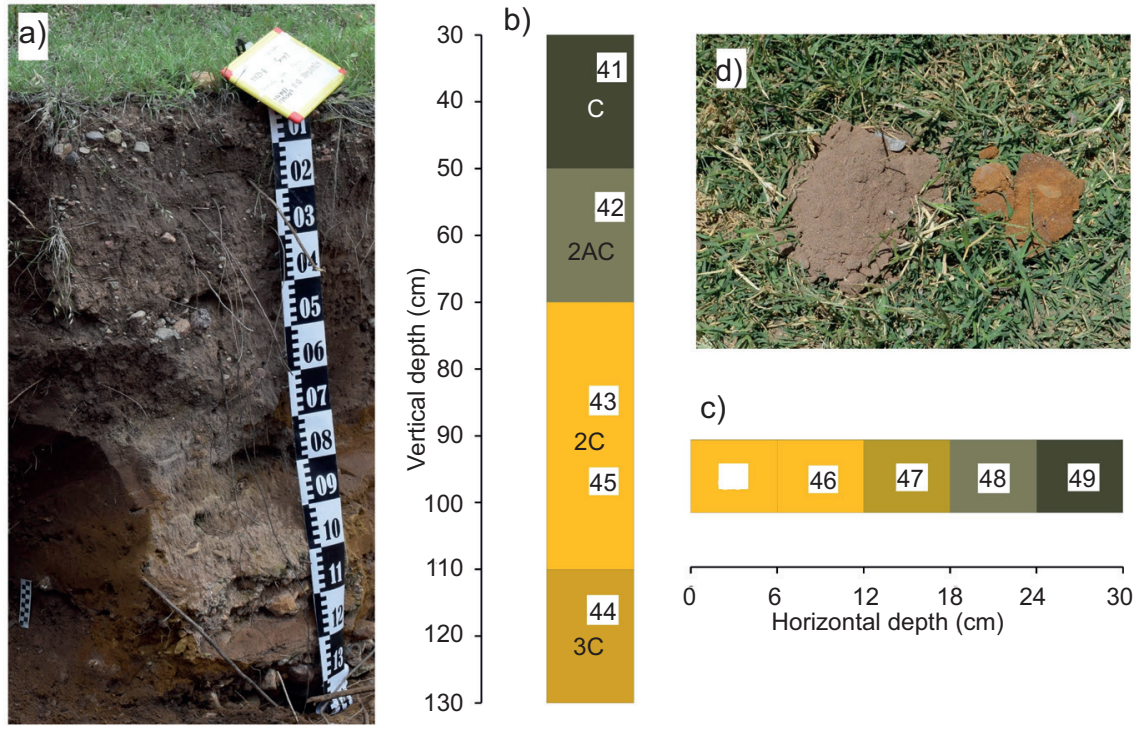

c)

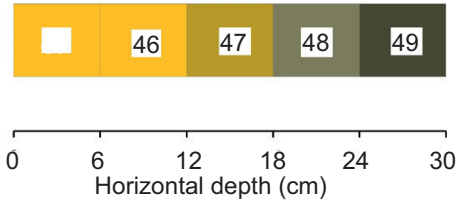

Fig. 2. (a) Image of the TIIZ1B profile, a poorly developed edaphic sequence formed by ACC-2AC-2C-3C horizons. (b) Vertical profile showing the location of samples 41 to 45. (c) Horizontal profile showing the location of samples 45 to 49. (d) The difference in color between the affected (ocher) and not affected (olive gray) material is notorious.

$\chi_{\mathrm{lf}}=\kappa_{\mathrm{lf}} \cdot($ volume/mass $)$

Frequency dependent magnetic susceptibility was calculated by

$\chi_{\mathrm{fd} \%}=\left[\left(\kappa_{\mathrm{lf}}-\kappa_{\mathrm{hf}}\right) / \kappa_{\mathrm{lf}}\right] \cdot 100 \%$

\section{Volume magnetic susceptibility (к) vs temperature (T) curves}

To measure $\kappa$ vs T curves, 3 to $5 \mathrm{~g}$ of each sample were heated from room temperature to $650{ }^{\circ} \mathrm{C}$, and then cooled to $50{ }^{\circ} \mathrm{C}$ at a rate of $10{ }^{\circ} \mathrm{C} / \mathrm{min}$, using a Bartington MS2WFP temperature controller. Magnetic susceptibility was measured with a Bartington MS2 magnetic susceptibilimeter and a Bartington MS2W sensor. The $\kappa$ vs T obtained data were smoothed by an adjacent-averaging method and derived to analyze the thermomagnetic behavior in terms of increasing-decreasing behavior and/or maxima-minima values.

\section{X-ray diffraction}

To assess the mineralogy of the materials, samples were milled, sieved with a 150 greed and analyzed with a portable Olympus Terra X-ray diffractometer, in an angular range from $5^{\circ}$ to $55^{\circ}$, with a scanning of 50 exposures of a Co radiation source. Analysis of data and identification of mineral phases was made with the XPowder software 2010.01.35 PRO and the PDF2 data basis.

\section{RESULTS}

\section{$\chi_{\text {If }}$ and $\chi_{\text {fd } \%}$ measurements}

The results from $\chi_{\mathrm{lf}}$ and $\chi_{\mathrm{fd}} \%$ measurements are shown in Table I. The lowest $\chi_{\text {lf }}$ value is from the dam precipitates sample, which is an order lower than the rest of the samples collection. The highest value is exhibited by the non-affected alluvial sediments of the TIIZ2 profile, which presents a very low $\chi_{\mathrm{fd}} \%$ value. On the other side, the topsoil has a lower $\chi_{\text {lf }}$ than the alluvial sediment, but a higher $\chi_{\mathrm{fd}} \%$. In the TIIZ1B profile we can observe that $\chi_{\text {If }}$ values are similar along the vertical and horizontal profiles: vertically, there is a slight increase downwards, reaching a maximum in the 45 sample; horizontally, the maximum is reached on the surface. In this profile, $\chi_{\text {lf values }}$ are low in general, but a slight increase can be noticed around samples 43 and 45 .

\section{$\kappa$ vs T curves}

During heating, the bulk magnetic susceptibility of samples from the acid solution precipitates showed a strong increase around $280{ }^{\circ} \mathrm{C}$ (Fig. 3, red line), reaching a maximum four-fold increase of the 
TABLE I. $\chi_{\text {lf }}$ AND $\chi_{\mathrm{fd}} \%$ MEASUREMENT* VALUES OBTAINED FROM THE SAMPLE COLLECTION USED IN THIS STUDY.

\begin{tabular}{lcccc}
\hline Sample ID & $\begin{array}{c}\text { Vertical } \\
\text { depth } \\
(\mathrm{cm})\end{array}$ & $\begin{array}{c}\text { Horizontal } \\
\text { depth } \\
(\mathrm{cm})\end{array}$ & $\begin{array}{c}\chi_{\mathrm{lf}} \\
\left(10^{-6} \mathrm{~m}^{3} / \mathrm{kg}\right)\end{array}$ & $\begin{array}{c}\chi_{\mathrm{fd} \%} \\
(\%)\end{array}$ \\
\hline $\begin{array}{l}\text { DamPrecipitates } \\
\text { TIIZ2 Topsoil }\end{array}$ & - & - & 0.014 & $*$ \\
TIIZ2 Upper & 17 & - & 0.092 & 1.74 \\
sediments & 292 & - & 0.147 & 0.91 \\
TIIZ1B 41 & 35 & - & 0.106 & 0.75 \\
TIIZ1B 42 & 55 & - & 0.114 & 1.15 \\
TIIZ1B 43 & 85 & - & 0.114 & 2.07 \\
TIIZ1B 44 & 115 & - & 0.105 & 1.05 \\
TIIZ1B 45 & 95 & 1 & 0.146 & 1.39 \\
TIIZ1B 46 & - & 8 & 0.120 & 0.70 \\
TIIZ1B 47 & - & 15 & 0.132 & 0.62 \\
TIIZ1B 48 & - & 21 & 0.123 & 0.38 \\
TIIZ1B 49 & - & 26 & 0.121 & 0.67 \\
\hline
\end{tabular}

*Measurement are uncertain due to low $\chi$ values.

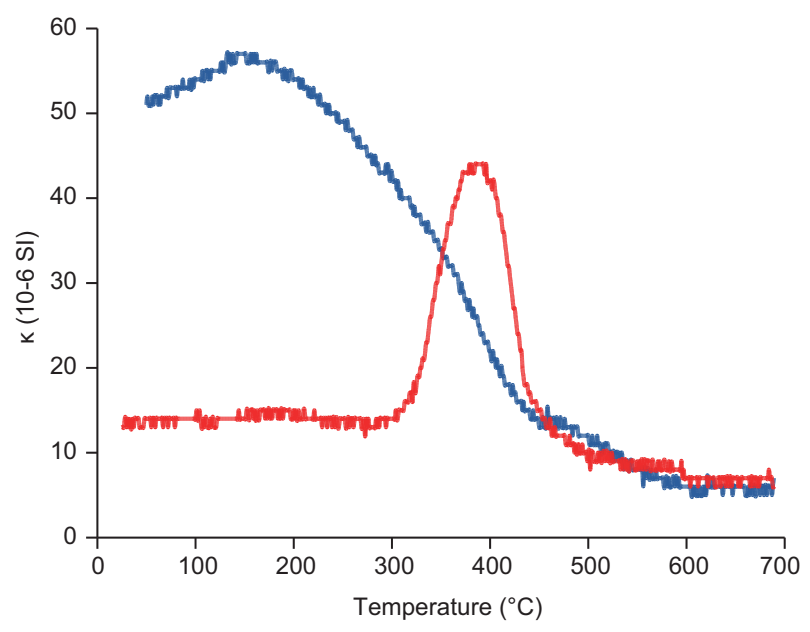

Fig. 3. Magnetic susceptibility vs temperature of acid solution dam precipitates. Red line represents heating, and blue line cooling.

initial $\kappa$ at around $380^{\circ} \mathrm{C}$, and then quickly decreasing between 400 and $500^{\circ} \mathrm{C}$. During this decreasing process, a change in the curve slope is observed around $450{ }^{\circ} \mathrm{C}$. Another small susceptibility drop is observed near $600{ }^{\circ} \mathrm{C}$. During cooling (Fig. 3, blue line) the susceptibility increases, reaching its maximum at $150{ }^{\circ} \mathrm{C}$, which is five times the initial value.

On the other hand, the behavior of magnetic susceptibility vs temperature curves from non-affected soil and sediment samples is completely different from that of the dam precipitates (Fig. 4). The magnetic susceptibility of non-affected soil sample shows a slight increase during heating at a constant rate from room temperature, reaching a maximum value at around 200 ${ }^{\circ} \mathrm{C}$. Afterwards, an important decrease of magnetic susceptibility is observed at around $510{ }^{\circ} \mathrm{C}$, indicating that the Curie temperature of (titano)magnetite has been reached. During cooling, $\kappa$ values are lower than during heating. For non-affected fluvial sediment samples, the behavior of $\kappa$ values during cooling is similar to their heating behavior (Fig. 4).

The samples from TIIZ1B vertical and horizontal profiles exhibit clear differences depending on their location within the profile. In the vertical profile, samples from the lower part, which have visible signs of being affected

a) Topsoil TIIZ2

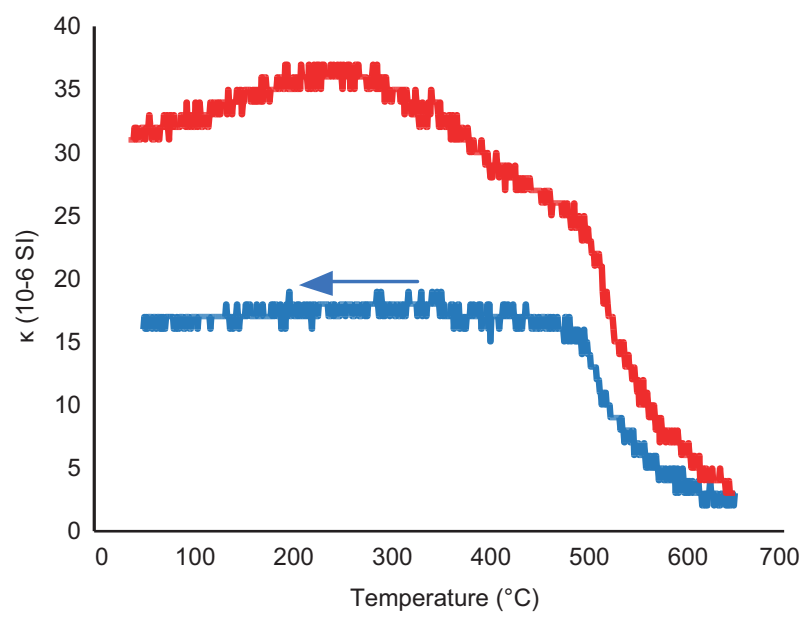

b) Alluvial sediment TIIZ2

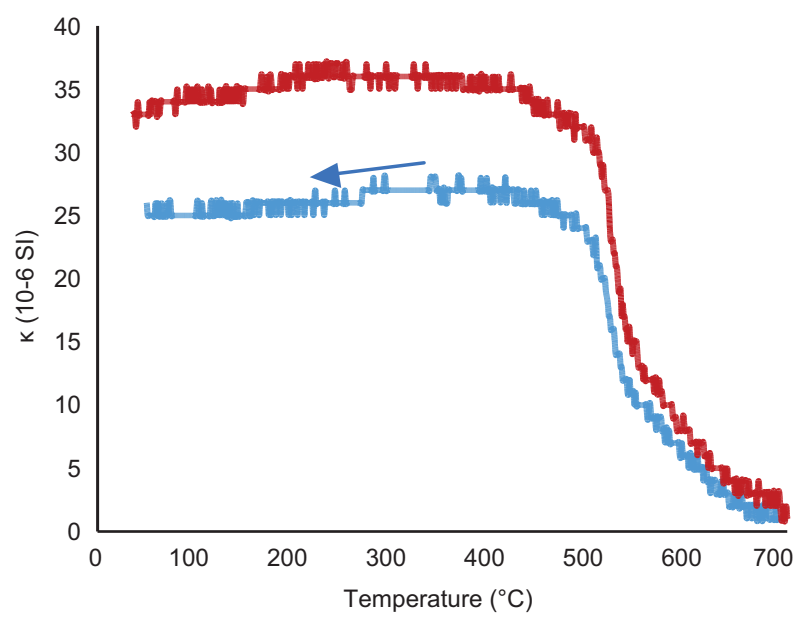

Fig. 4. Magnetic susceptibility vs temperature of (a) non-affected soil samples and (b) non-affected sediment sample. 
(yellowish pigments), present a sudden strong raise of $\kappa$ values during heating at around $330^{\circ} \mathrm{C}$, reaching a maximum value around $430^{\circ} \mathrm{C}$, and a quick decrease of susceptibility around $500^{\circ} \mathrm{C}$ (Fig. 5b). This behavior indicates that a transformation of a weak magnetic mineral into a strong magnetic mineral occurs. On the other hand, samples from the non-affected part do not show such behavior. Nonaffected samples initially exhibit a small increase due to the unblocking of SP magnetite particles, and a strong loss of magnetic susceptibility around $550^{\circ} \mathrm{C}$ (Fig. 5a), which indicates that magnetic behavior of non-affected samples is dominated by magnetite. During cooling, both samples exhibit a similar ten- dency, that is a strong increase in $\kappa$ values, reaching a maximum at around $400{ }^{\circ} \mathrm{C}$. It is remarkable that the magnetic susceptibility of the affected sample is twice the value of the non-affected one after heating and cooling cycle at room temperature, while $\kappa$ values of both materials are very similar before heating.

Comparing the different affected samples from the horizontal sampling, it is observed that the increase during heating of the superficial sample is higher than the increases of inner samples (Fig. 6b), but it decreases with depth. In consequence, the inner sample does not present any increase and its behavior is identical to that shown by the non-affected sample from the upper part of vertical profile (Fig. 6a).
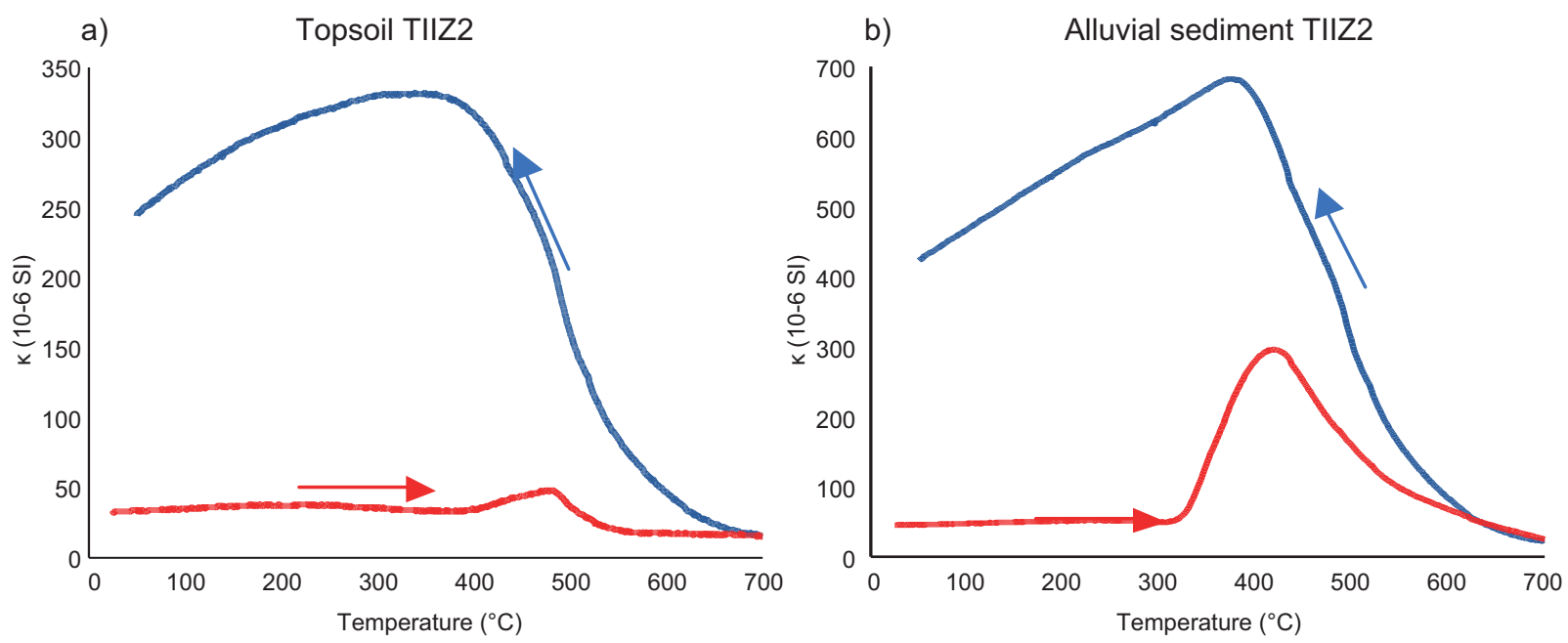

Fig. 5. Magnetic susceptibility vs temperature of two samples from the TIIZ1B profile form (a) ssthe non-affected upper part and (b) the affected lower part, which shows a strong increase of $\kappa$ values during heating.
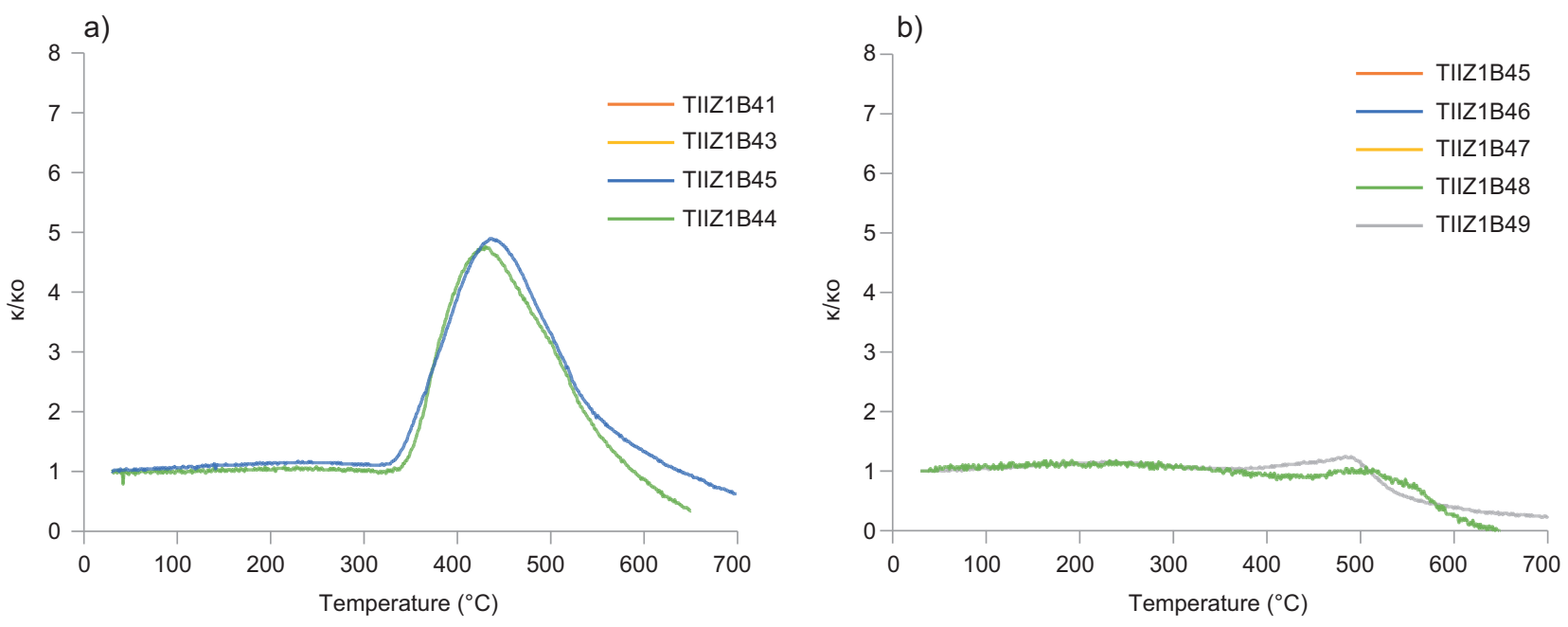

Fig. 6. Magnetic susceptibility normalized by the initial value, comparative for heating curves among samples from (a) vertical and (b) horizontal profiles. 


\section{Mineral assemblage by XRD}

Based on x-ray diffractograms, mineralogically the sample from the acid solution dam precipitates is constituted by silicate minerals, such as quartz, intermediate plagioclase, mica and phyllosilicates, a high content of jarosite, and some content of iron oxides has hematite and goethite (Fig. 7a). After heating at $400{ }^{\circ} \mathrm{C}$, it is observed that jarosite peaks decrease, indicating the partial loss of this mineral. A slight increase of hematite content is also observed
(Fig. 7b). After heating at $600{ }^{\circ} \mathrm{C}$ jarosite peaks disappear and new peaks appear that correspond to a strong increase in hematite content (Fig. 7c).

The diffractogram of the TIIZ1B43 sample (affected) show a mineralogy basically constituted by silicate minerals, but the presence of jarosite is not detected by the XRD measurement (Fig. 8a), which could be due to a low concentration and/or crystallinity of this mineral. Very similar mineralogy is observed in diffractograms of non-affected samples (Fig. 8b).
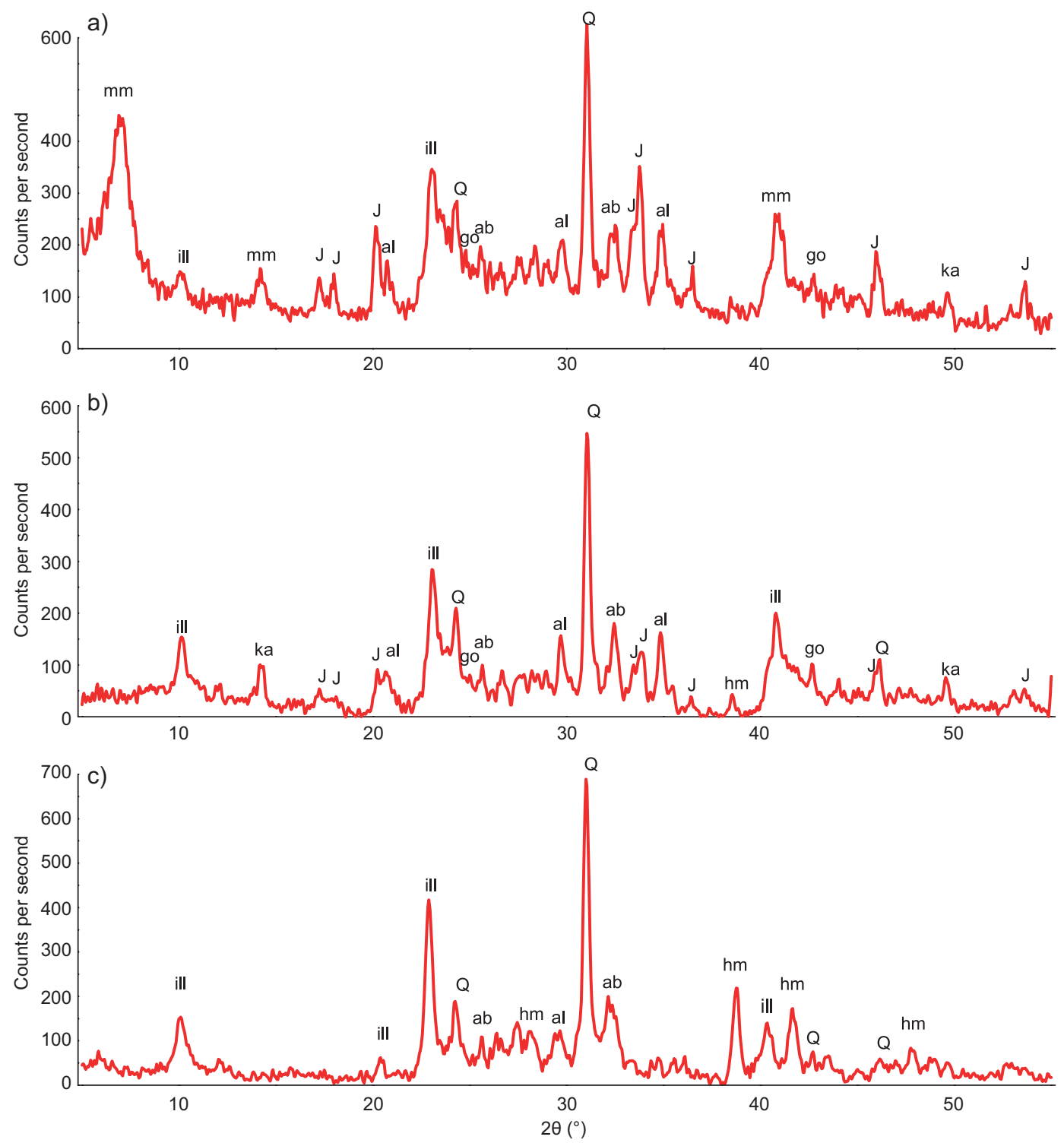

Fig. 7. X-ray diffractograms of the dam precipitates sample at different temperature treatments. (a) The nonheated sample presents a strong signal of jarosite. (b) The sample heated at $400{ }^{\circ} \mathrm{C}$ exhibits a decrease in jarosite signal. (c) In the sample heated at $600{ }^{\circ} \mathrm{C}$ jarosite lines disappear and hematite lines appear. ab: albite, al: alunite, fs: feldspar, go: goethite, hm: hematite, ill: illite, J: jarosite, ka: kaolinite, mm: montmorillonite, Q: quartz. 

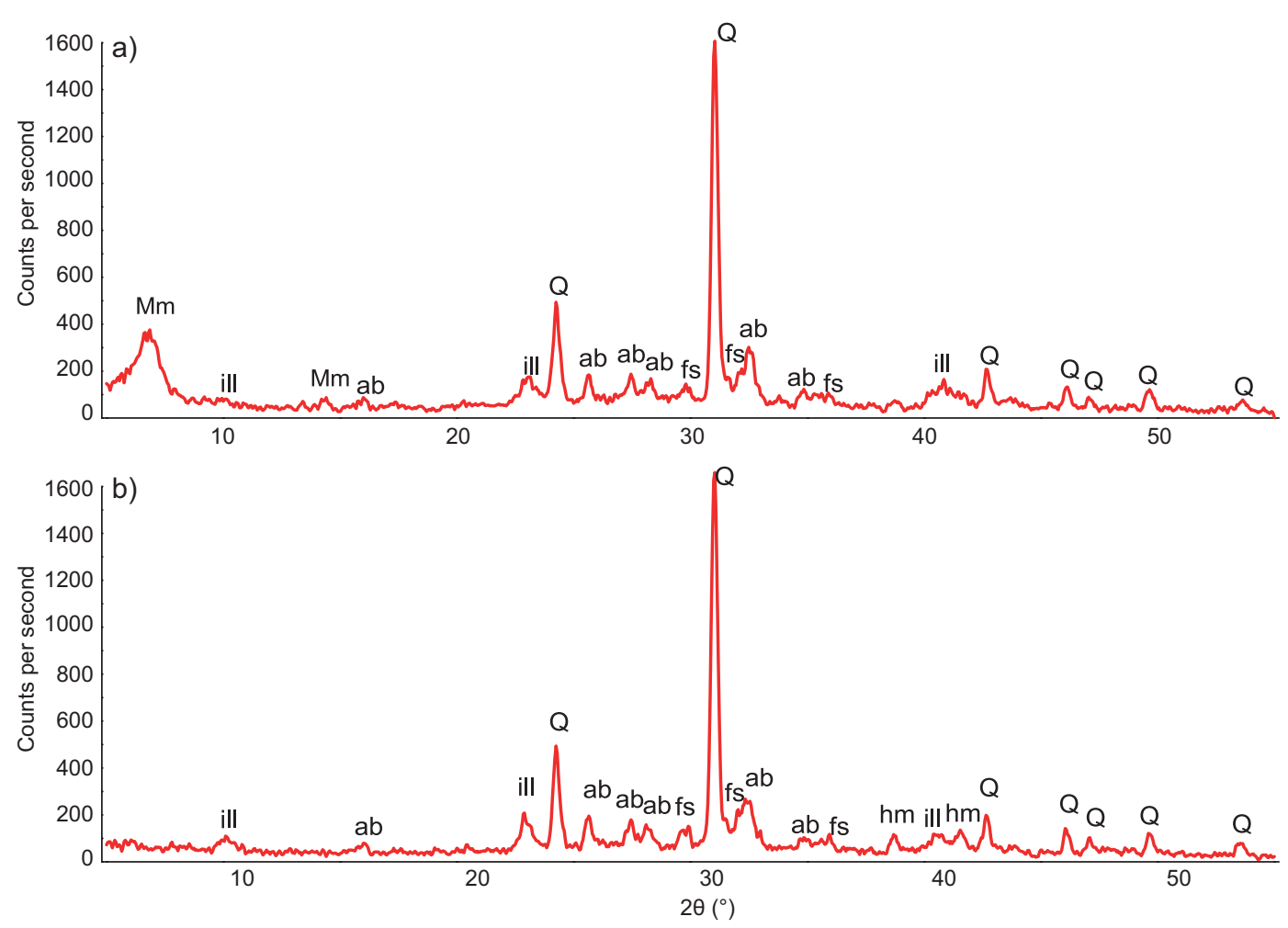

Fig. 8. X-ray difractograms of samples from (a) TIIZ1B 43, with presence of dam precipitates, and (b) TIIZ2, where topsoil samples with no presence of dam precipitates show the same mineralogy. ab: albite, al: alunite, fs: feldspar, hm: hematite, ill: illite, Mm: montmorillonite, Q: quartz.

\section{DISCUSSION}

$\chi_{\text {If }}$ is the lowest value of the acid solution dam precipitates $\left(0.014 \times 10^{-6} \mathrm{~m}^{3} / \mathrm{kg}\right)$, one order lower than soils and sediments samples, indicating that this is one of those cases in which contamination does not contribute to the content's increase of ferrimagnetic particles, which are naturally found in soils and sediments in the area. This is observed in the $\kappa$ vs $T$ curves of non-affected samples that exhibit the (titano)magnetite behavior. The presence of magnetite has been reported in rock formations from which the sediments of the basin come (del Río-Salas et al. 2013).

In general, $\chi_{\mathrm{fd}} \%$ values are very low (from 0.38 to $2.07 \%$ ), indicating a poor presence of SP particles (magnetic nanoparticles), being slightly higher in the non-affected topsoil. Comparing $\chi_{\mathrm{fd}} \%$ values of samples from the TIIZ1B vertical profile, a slight increase of this parameter is detected in samples 43 and 45 (2.04 and $1.39 \%$, respectively), which are located in the area most notoriously impregned by the spilled material, contrasting with the values rest of the vertical profile, which that do not exceed
$1.15 \%$. In the horizontal profile, the highest value corresponds to the superficial sample 45 , while the rest of the profile does not exceed $0.7 \%$. This may indicate that materials coming from the spilling carry a small amount of SP particles.

The trends for both $\chi_{\mathrm{lf}}$ and $\chi_{\mathrm{fd}} \%$ do not coincide with those generally reported in pollution studies using magnetic properties, where $\chi$ and other parameters are commonly enhanced by MD (course grained) magnetite particles of anthropogenic origin (Yang et al. 2007, Zhu et al. 2013). In this case, anthropogenic activity does not produce such particles but generates very fine-grained particles of iron minerals whose magnetic behavior is paramagnetic, as in the cases of jarosite and ferrihydrite, or antiferromagnetic, as in goethite.

\section{Mineral transformation during heating}

Jarosite and other oxyhydroxy-sulfites, which are very common in mine acid drainage environments (Murad and Rojik 2004), are generated under low $\mathrm{pH}$ conditions and high sulfate concentrations $(\mathrm{pH}$ $1.5-3<,[\mathrm{SO}]>3000 \mathrm{mg} / \mathrm{l})$. They also occur in the hydro-metallurgic process, due to the acid solution 
used to lixiviate the minerals of economic interest from the extracted materials.

It is reported that jarosite presents different reactions during heating, at different temperatures, depending on cation content. Thermogravimetrical studies of this mineral have reported that a series of mass losses are observed during heating, the fist at $130{ }^{\circ} \mathrm{C}$ due to dehydroxylation, and others at 330,500 and $620^{\circ} \mathrm{C}$ due to desulphation (Frost et al. 2005). The second mass loss coincides with the temperature at which $\kappa$ starts increasing in our samples. Then, if iron has been desulphated in presence of an oxygen atmosphere, the formation of iron oxides occurs, which explains the rise of $\kappa$ values.

Another mineral that displays a transition at similar temperature is ferrihydrite. Thermogravimetric and differential thermal analyses of this mineral reported by Eggleton and Fitzpatrick (1988) showed that an exothermic reaction occurs at $340^{\circ}-355^{\circ} \mathrm{C}$ as a result of maghemite growth. A second exotherm at $450{ }^{\circ} \mathrm{C}$ is interpreted as a result from the conversion of maghemite to hematite. This mineral was not detected by XRD in any sample, but it is well known that ferrihydrite is elusive to this method due to is amorphous structure and small grain size (close to or below $10 \mathrm{~nm}$ ) (Murad and Rojik 2004).

It is also known that jarosite is a meta-stable mineral and it is easily transformed by whetering into other minerals. Jarosite is a precursor of some iron oxyhydroxides such as ferrihydrite and goethite, therefore the presences of both jarosite and ferrihydrite is possible in acid solution dam precipitates and contaminated samples.

Another iron mineral that can be altered during heating is goethite. Hanesch et al (2006) reported that this mineral, when heated above $400{ }^{\circ} \mathrm{C}$ in the presence of organic matter, transforms into maghemite, and without organic matter, it transforms directly to hematite.

Therefore, the $\kappa$ increase during heating may be due to the alteration of this group of iron bearing minerals, which has been reported as occurring very commonly in acid solution drainage and mine wastes (Murad and Rojik 2004). Jarosite and goethite were directly identified by XRD in the dam precipitates. Ferrihydrite was not detected by this technique, probably due to its characteristic poor crystallinity and nanometric particle size, but it is very likely that it plays an important role in $\kappa$ increasing during heating. It was also observed that the temperature from which $\kappa$ values start increasing coincides with the temperature reported for beginning of the alteration of jarosite, goethite and ferrihydrite to maghemite, a ferrimagnetic mineral, which explains the increase of magnetic susceptibility.

\begin{abstract}
Alteration index
Some works have proposed alteration indexes based on $\kappa$ ratios during heating and cooling (e.g., Böhnel et al. 2002, Hrouda 2003, Abrajevitch and Kodama 2011). In this study, an alteration index $\kappa_{\max } / \kappa_{\mathrm{o}}$ (which is the ratio of the maximum $\kappa$ value reached during heating and the value of $\kappa$ at room temperature before heating) is proposed. This index aims to quantify the $\kappa$ value increase due to alteration of iron bearing minerals during heating, and, in the same way, to assess qualitatively the impact degree.

Values of $\kappa$ and some characteristic temperatures of THE TIIZ1B profile samples are shown in Table II. $\kappa_{0}$ is the magnetic susceptibility at room temperature
\end{abstract}

TABLE II. MAGNETIC SUSCEPTIBILITY VALUES DURING HEATING OF SAMPLES FROM THE TIIZ1B VERTICAL AND HORIZONTAL PROFILES, TEMPERATURES AT WHICH SOME CHANGES IN MAGNETIC SUSCEPTIBILITY BEHAVIOR OCCUR, AND $\kappa_{\max } / \kappa_{\mathrm{o}}$ RATIOS AS INDICES OF ALTERATIONS.

\begin{tabular}{lccccc}
\hline & $\begin{array}{c}\kappa_{\mathrm{o}} \\
\left(\mathrm{T}=30{ }^{\circ} \mathrm{C}\right)\end{array}$ & $\begin{array}{c}\mathrm{T} \text { when } \kappa \text { increase } \\
\text { starts }\left({ }^{\circ} \mathrm{C}\right)\end{array}$ & $\begin{array}{c}\kappa_{\max } \\
\text { (during heating) }\end{array}$ & T of $\kappa_{\max }\left({ }^{\circ} \mathrm{C}\right)$ & $\kappa_{\max } / \kappa_{\mathrm{o}}$ \\
\hline Dam precipitates & 13 & 265 & 44 & 380 & 3.38 \\
TIIZ1B 41 & 33 & 385 & 48 & 480 & 1.45 \\
TIIZ1B 43 & 46 & 320 & 296 & 420 & 6.72 \\
TIIZ1B 44 & 38 & 330 & 179 & 435 & 4.71 \\
TIIZ1B 45 & 48 & 330 & 235 & 435 & 4.89 \\
TIIZ1B 46 & 47 & 330 & 197 & 430 & 4.19 \\
TIIZ1B 47 & 30 & 420 & 42 & 490 & 1.4 \\
TIIZ1B 48 & 29 & 450 & 33 & 506 & 1.13 \\
TIIZ1B 49 & 45 & 395 & 56 & 485 & 1.24 \\
\hline
\end{tabular}


before heating. The temperature when $\kappa$ values start increasing is also shown for its correlation with some iron-bearing mineral transformation. $\kappa_{\max }$ represents the highest value of magnetic susceptibility reached during heating. The proposed index of alteration is the $\kappa_{\max } / \kappa_{\mathrm{o}}$ ratio, where higher values mean a greater amount of material coming from the acid solution leak.

Samples 41 (from the upper part of the vertical profile), 47, 48 and 49 (from the deeper part of horizontal profile) show a low value of $\kappa_{\max } / \kappa_{0}$ ratio (from 1.13 to 1.45). The increase is not attributed to the transformation of iron-bearing minerals but to ferrimagnetic minerals present in the sample. Values of the $\kappa_{\max } / \kappa_{0}$ ratio in samples $43,44,45$ and 46 (4.19 to 6.72) are three to five times higher than those of non-affected samples. Comparing the index between samples at the surface of the profile $(43,44$ and 45$)$ and deeper samples in the horizontal profile (46 to 49), it is observed that the latter exhibit lower values. In general, it is observed that samples closer to the surface have higher values of this ratio. Therefore, the $\kappa_{\max } / \kappa_{\mathrm{o}}$ ratio is useful for quantifying roughly the content of material coming from an acid solution leak. It is also observed that the $\kappa_{\max } / \kappa_{0}$ ratio for dam precipitates is lower that in samples 43 to 46 . This may be due to the organic matter content in the soil and sediment samples, which promotes the alteration of iron-bearing minerals (Hanesch et al. 2006).

Table III shows a comparison between the alteration index proposed in this paper and the one from by Abrajevitch and Kodama (2011), which is calculated with saturation magnetization data, but it is also possible to calculate it with $\kappa$ data. It consists of approximating the area under the $\kappa$ vs T plot (which corresponds to $\kappa$ increase due to the mineral transformation) by means of a triangle with base of

TABLE III. COMPARISON BETWEEN THE ALTERATION INDEX PROPOSED IN THIS STUDY AND $\left(\mathrm{T}_{\max }\right.$ $\left.-\mathrm{T}_{\mathrm{o}}\right) \times\left(\kappa_{\max }-\kappa_{\mathrm{To}}\right)$.

\begin{tabular}{lcc}
\hline & $\kappa_{\max } / \kappa_{\mathrm{o}}$ & $\left(\mathrm{T}_{\max }-\mathrm{T}_{\mathrm{o}}\right) \times\left(\kappa_{\max }-\kappa_{\mathrm{To}}\right)$ \\
\hline Dam precipitates & 3.38 & 3565 \\
TIIZ1B 41 & 1.45 & 1425 \\
TIIZ1B 43 & 6.72 & 24600 \\
TIIZ1B 44 & 4.71 & 14910 \\
TIIZ1B 45 & 4.89 & 19110 \\
TIIZ1B 46 & 4.19 & 14700 \\
TIIZ1B 47 & 1.4 & 1050 \\
TIIZ1B 48 & 1.13 & 392 \\
TIIZ1B 49 & 1.24 & 900 \\
\hline
\end{tabular}

$2\left(\mathrm{~T}_{\max }-\mathrm{T}_{0}\right)$ and height of $\left(\kappa_{\max }-\kappa_{0}\right)$. The comparison shows that trends for both indices coincide, and samples with a higher value of the $\kappa_{\max } / \kappa_{0}$ ratio also present a greater area under the alteration peak.

\section{CONCLUSION}

Magnetic behavior during heating of affected and not-affected samples were successfully contrasted. Affected materials exhibited a $\kappa$ increase while heating, corresponding to the transformations of jarosite, ferrihydrite and goethite coming from the acid solution leak. It was also observed, in TIIZ1B profile, that stronger affected samples exhibited a higher increase in magnetic susceptibility, and this behavior can be quantified by the $\mathrm{\kappa max} /$ кo ratio. On the other hand, XRD allowed to identify jarosite in dam precipitates where it is found in high concentrations, but it was not possible to identify it by XRD in other affected samples due to its low concentration. Then, the thermal magnetic behavior could be an auxiliary indirect indicator for the presence of iron-bearing materials generated by mine activities, and the proposed ratio could be a qualitatively indicator for concentration of these minerals.

\section{ACKNOWLEDGMENTS}

We thank Fideicomiso Río Sonora grant No. 80724 for the financial support of this study.

\section{REFERENCES}

Abrajevitch A. and Kodama K. (2011). Diagenetic sensitivity of paleoenvironmental proxies: A rock magnetic study of Australian continental margin sediments. Geochem. Geophys. Geosys. 12 (5). https://doi. org/10.1029/2010GC003481

Blowes D.W., Ptacek C.J. and Jurjover J. (2003). Mill tailings: hydrogeology and geochemistry. In: Enviromental aspects of mine waste, Short Course Series, Vol. 31 (J.L. Jambor, D.W. Blowes and A.I.M. Ritchie, Eds.). Mineralogical association of Canada, Vancouver British Columbia, Canada, pp. 96-116.

Böhnel H., McIntosh G. and Sherwood G. (2002). A parameter characterizing the irreversibility of thermomagnetic curves. Phys. Chem. Earth. 27 (25-31), 13051309. https://doi.org/10.1016/S1474-7065(02)00124-9

Calmus T., Valencia-Moreno M., Del Río-Salas R., Ochoa-Landín L., and Mendivil-Quijada H. (2018). 
A multi-elemental study to establish the natural background and geochemical anomalies in rocks from the Sonora river upper basin, NW Mexico. Rev. Mex. Cienc. Geol. 35 (2), 158-167. https://doi.org/10.22201/ cgeo.20072902e.2018.2.605

Chaparro M.A.E., Chaparro M.A.E., Rajkumar P., Ramasamy V. and Sinito A.M. (2011). Magnetic parameters, trace elements and multivariate statistical studies of river sediments from south eastern India: A case study from Vellar River. Environ. Earth Sci. 63 (2), 297-310. https://doi.org/10.1007/s12665-010-0704-2

Del Río-Salas R., Ochoa-Landín L., Valencia-Moreno M., Calmus T., Meza-Figueroa D., Salgado-Souto S., Kirk J., Ruiz J. and Mendívil-Quijada H. (2015). New U$\mathrm{Pb}$ and Re-Os geochronology of Laramide porphyry copper mineralization along the Cananea lineament, northeastern Sonora, Mexico: Contribution to the understanding of the Cananea copper district. Ore Geol. Rev. 81 (3), 1125-1136. https://doi.org/ 10.1016/j. oregeorev.2015.11.029

Del Río-Salas R., Ochoa-Landín L., Ruíz J., Eastoe C., Meza-Figueroa D., Zuñiga Hernández H., MendívilQuijada H. and Quintanar-Ruíz F. (2013). Geology, stable isotope, and $\mathrm{U}-\mathrm{Pb}$ geochronology of the Mariquita porphyry copper and Lucy $\mathrm{Cu}-\mathrm{Mo}$ deposits, Cananea District, Mexico: A contribution to regional exploration. J. Geochem. Explor. 124, 140-154. https:// doi.org/10.1016/j.gexplo.2012.08.016

Eggleton R. and Fitzpatrick R.W. (1988). New data and a revised structural model for ferrihydrite, Clays Clay Miner. 36 (2), 111-124. https://doi.org/10.1346/ CCMN.1988.0360203

Frost R.L., Weier M.L. and Martens W. (2005). Thermal decomposition of jarosites of potassium, sodium and lead. J. Therm. Anal. Cal. 82(1), 115-118. https://doi. org/10.1007/s10973-005-0850-z

Frost R.L., Wain D., Martens W.N., Locke A.C., MartínezFrías J. and Rull F. (2007). Thermal decomposition and X-ray diffraction of sulphate efflorescent minerals from El Jaroso Ravine, Sierra Almagrera, Spain. Thermochim. Acta 460 (1-2), 9-14. https://doi.org/10.1016/j. tca.2007.05.011

Hanesch M., Stanjek H. and Petersen N. (2006) Thermomagnetic measurements of soil iron minerals: the role of organic carbon. Geophys. J. Int. 165 (1), 53-61. https://doi.org/10.1111/j.1365-246X.2006.02933.x

Hrouda F. (2003) Indices for numerical characterization of the alteration processes of magnetic minerals taking place during investigation of temperature variation of magnetic susceptibility. Stud. Geophys. Geod. 47(4), 847-861. https://doi.org/10.1023/A:1026398920172

Jambor J.L. and Owens D.R. (1993) Mineralogy of the tailings impoundment at the former $\mathrm{Cu}-\mathrm{Ni}$ deposit of
Nickel Rim Mines Ltd., eastern edge of the Sudburystructure, Ontario. Division Report MSL 93-4 (CF), CANMET, Energy, Mines and Resources, Canada.

Magiera T., Mendakiewicz M., Szuszkiewicz M., Jabłońska M. and Chróst L. (2016). Technogenic magnetic particles in soils as evidence of historical mining and smelting activity: A case of the Brynica River Valley, Poland. Sci. Total Environ. 566567(1), 536-551. https://doi.org/10.1016/j.scitotenv.2016.05.126

Magiera T., Zawadzki J., Szuszkiewicz M., Fabijanczyk P., Steinnes E., Fabian K. and Miszczak E. (2018). Impact of an iron mine and a nickel smelter at the Norwegian/ Russian border close to the Barents Sea on surface soil magnetic susceptibility and content of potentially toxic elements. Chemosphere 195(1), 48-62. https:// doi.org/10.1016/j.chemosphere.2017.12.060

Matasova G.G., Kazansky A.Y., Bortkinova S.B. and Airijants A.A. (2005). The use of magnetic methods in an environmental study of areas polluted with non-magnetic wastes of the mining industry (Salair region, Western Siberia, Russia). Geochem. Explor. Environ. A. 5(1), 75-89. https://doi.org/10.1144/14677873/03-058

Mitov I., Paneva D. and Kunev B. (2002). Comparative study of the thermal decomposition of iron oxyhydroxides. Thermochim. Acta 386 (2), 179-185. https://doi. org/10.1016/S0040-6031(01)00808-5

Murad E. and Rojik P. (2004). Jarosite, schwertmannite, goethite, ferrihydrite and lepidocrocite: the legacy of coal and sulfide ore mining. Memorias. SuperSoil 2004: 3rd Australian New Zealand Soils Conference, University of Sydney, Australia. December 5-9 2004.

Ochoa-Landín L. and Echávarri A. (1978). Observaciones preliminares sobre la secuencia de las intrusiones hipabisales en el tajo Colorada-Veta del distrito minero de Cananea: Universidad de Sonora, Boletín del Departamento de Geología v. 1, p. 57-60

Ochoa-Landín L., Pérez-Segura E., Del Río-Salas R., Valencia-Moreno M. (2011). Depósitos minerales de Sonora, México. In: Panorama de la geología de Sonora, México (T. Calmus, Ed.). Universidad Nacional Autónoma de México, Instituto de Geología, Boletín 118, cap. 9, p. 298-331.

Peña J.A., Manteca J.I., Martínez-Pagán P., Teixido T. (2013). Magnetic gradient map of the mine tailings in Portman Bay (Murcia, Spain) and its contribution to the understanding of the bay infilling process. J. Appl. Geophys. 95(1), 115-120. DOI : 10.1016/j.jappgeo.2013.05.011

Pérez I. (2015). Uso de parámetros indirectos en la determinación de la contaminación de suelos por elementos potencialmente tóxicos en zonas minero-metalúrgicas. 
Tesis de Doctorado. Posgrado en Ciencias de la Tierra, Universidad Nacional Autónoma de México. Ciudad de México, México, 197 pp.

Quijano L., Chaparro M.A.E., Marié D.C., Gaspar L. and Navas A. (2014). Relevant magnetic and soil parameters as potential indicators of soil conservation status of Mediterranean agroecosystems. Geophys. J. Int. 198 (3), 1805-1817. https://doi.org/10.1093/gji/ggu239

Ramos D. (2017) Evaluación de la contaminación y del riesgo ambiental en suelos y sedimentos afectados en la cuenca del Río Sonora. Tesis de Maestría. Posgrado en Ciencias de la Tierra, Universidad Nacional Autónoma de México. Ciudad de México, México, 127 pp.

Rivera-Uria M.Y., Ziegler-Rivera F.R.A., Díaz-Ortega J., Prado-Pano B., Romero, F.M. (2018). Effect of an acid mine spill on soils in Sonora River Basin: Micromorphological indicators. Spanish J. Soil Sci. 8(2), 258-274. https://doi.org/10.3232/SJSS.2018.V8.N2.08

Romero-Lázaro E.M., Ramos-Pérez D., Romero F.M. and Sedov S. (2019). Indicadores indirectos de contaminación residual en suelos y sedimentos de la cuenca del Río Sonora, México. Rev. Int. Contam. Ambie. 35 (2) 371-386. https://doi.org/10.20937/ RICA.2019.35.02.09

Romero Lázaro E.M. (2018). Minerales arcillosos de los suelos y paleosuelos del arroyo Tinajas, Cananea, Sonora: caracterización, procedencia y respuesta ante un vertido minero. Tesis de Maestría. Instituto de Geología, Universidad Nacional Autónoma de México, Ciudad de México, México, 111 pp.

Scholger R. (1998). Heavy metal pollution monitoring by magnetic susceptibility measurements applied to sediments of the river Mur (Styria, Austria). Eur. J. Environ. Eng. Geophys. 3(1), 25-37.

Strzyszcz Z. and Magiera T. (1998). Magnetic susceptibility and heavy metals contamination in soils of Southern Poland. Phys. Chem. Earth 23(9-10), 1127-1131. https://doi.org/10.1016/S0079-1946(98)00140-2

Vega-Granillo E.L., Cirett-Galán S., de la Parra-Velasco, M.L. and Zavala-Juárez R. (2011). Hidrogeología de Sonora, México. In: Panorama de la geología de Sonora, México (T. Calmus, Ed.): Universidad Nacional Autónoma de México, Instituto de Geología, Boletín 118, cap. 8, p. 267-298.

Yang T., Liu Q.S., Chan L.S. and Liu Z.D. (2007) Magnetic signature of heavy metals pollution of sediments: case study from the East Lake in Wuhan, China. Environ. Geol. 52(8), 1639-1650. https://doi.org/10.1007/ s00254-006-0609-2

Zhu, Z.M., Li, Z.G., Bi, X.Y., Han, Z.X. and Yu, G.H., (2013) Response of magnetic properties to heavy metal pollution in dust from three industrial cities in China. J. Hazard. Mater. 246-247(1), p. 189-198. https://doi. org/10.1016/j.jhazmat.2012.12.024 